\title{
Assessment of Health Workers' Concern about COVID-19 Pandemic: Implication for Surveillance Activities among Primary Health Care Workers in Oyo State, South-Western Nigeria
}

\author{
Olaniyan Akintunde Babatunde ${ }^{1,2^{*}}\left(\mathbb{D}\right.$, Muideen Babatunde Olatunji ${ }^{1}$, \\ Akande Roseline Oluyemisi ${ }^{3}$, Joseph Muyiwa Olumoyegun ${ }^{4}$, Adekunbi Mofoyeke Babatunde ${ }^{5}$ \\ ${ }^{1}$ Oyo State Primary Health Care Board, State Secretariat, Agodi, Ibadan, Oyo State, Nigeria \\ ${ }^{2}$ Oriire Local Government Health Authority, Ikoyi-Ile, Oyo State, Nigeria \\ ${ }^{3}$ Department of Community Medicine, Bowen University, Iwo, Osun State, Nigeria \\ ${ }^{4}$ Department of Geography, Faculty of the Social Sciences, University of Ibadan, Oyo State, Nigeria \\ ${ }^{5}$ Tax Audit Field Unit, Lagos State Internal Revenue Service, Alausa, Ikeja, Lagos State, Nigeria \\ Email: `tundebabson23@gmail.com, tundeolatunji2002@yahoo.com, rossmodupe@yahoo.com, joephine2011@gmail.com, \\ kunbid1@gmail.com
}

How to cite this paper: Babatunde, O.A. Olatunji, M.B., Oluyemisi, A.R., Olumoyegun, J.M. and Babatunde, A.M. (2021) Assessment of Health Workers' Concern about COVID-19 Pandemic: Implication for Surveillance Activities among Primary Health Care Workers in Oyo State, South-Western Nigeria. Open Journal of Epidemiology, 11, 189-206.

https://doi.org/10.4236/ojepi.2021.112017

Received: March 1, 2021

Accepted: May 25, 2021

Published: May 28, 2021

Copyright $\odot 2021$ by author(s) and Scientific Research Publishing Inc. This work is licensed under the Creative Commons Attribution International License (CC BY 4.0).

http://creativecommons.org/licenses/by/4.0/ c) (i) Open Access

\begin{abstract}
Background: The outbreak of COVID-19 has continued to threaten the existence of the human race. The novelty and unstable epidemiologic pattern of the virus had generated so much concern among the global health experts. These concerns were found to be escalated among the frontline health care workers to the extent of impeding the timeliness of the response activities. To slow down the spread of the already established community transmission through the surveillance activities, the concern of the health workers at the community level needs to be addressed. Therefore, this study assessed the concern about COVID-19 pandemic among primary health workers in Oyo State, Nigeria. Methods: This was an online cross-sectional survey conducted among primary health care workers in Oyo State between March and April 2020. Using a two-stage sampling technique, we recruited 284 respondents. A semi-structured questionnaire linked to the Google form was used to collect data. Data were analyzed using IBM SPSS version 25; bivariate analysis was done using Chi-square and binary logistic regression was used to identify the predictors of health workers' concern at $5 \%$ level of significance. Results: The mean age of respondents was $45.0 \pm 9.0$ years. The proportion of the respondents who had good knowledge of COVID-19 was $52.5 \%$. In the domains of
\end{abstract}


concern, $66.9 \%, 53.2 \%, 51.4 \%$, and $46.5 \%$ of the respondents expressed government-related, self-satisfaction related, work-related and social-status related concerns respectively. Male respondents were less likely to express concern about COVID-19 compared with their female counterparts ( $\mathrm{aOR}=0.39$, $95 \% \mathrm{CI}=0.20$ - 0.76). Nurses/midwives $(\mathrm{aOR}=0.21,95 \% \mathrm{CI}=0.05-0.85)$ had lesser likelihood of expressing concern about COVID-19 while middle staff $(\mathrm{aOR}=2.5,95 \% \mathrm{CI}=1.18-5.39)$ and income earner of $\geq \mathrm{N} 200,000(\mathrm{aOR}$ $=2.3,95 \% \mathrm{CI}=1.34$ - 3.92) had higher likelihood of expressing concern about COVID-19. Conclusion: The study highlights an average knowledge of COVID-19 among the respondents. Government-related and self-satisfaction related concerns were expressed by the majority of the Primary Health Care (PHC) workers. Now that the second wave of COVID-19 is moving with much more fatality across much of Africa, including Nigeria, it is therefore imperative to address these concerns through a holistic policy that addresses the welfare, safety and capacity building of the health care workers (HCWs).

\section{Keywords}

Concerns, Health Workers, COVID-19, Surveillance, Nigeria

\section{Background}

Currently, global health experts are contending with the pandemic caused by coronavirus disease 2019 (COVID-19), the magnitude of which exceeds that of Ebola Virus Disease (EVD), Middle East Respiratory Syndrome (MERS) and Severe Acute Respiratory Syndrome (SARS) combined [1]. This pandemic has generated an unprecedented concern in the annals of history of human existence. Consequent upon this concern, the World Health Organization (WHO) declared it a public health emergency of international concern (PHEIC) on 30th January 2020 and classified it as a pandemic on 11th March 2020 [1]. The anxiety generated could probably be premised on the novelty and unstable epidemiologic parameters of the disease caused by severe acute respiratory syndrome-coronavirus-2 (SARS-COV-2). This new virus was first isolated from the hospitalized patients who presented with pneumonia-like symptoms in Wuhan, the industrial city of China, in December 2019 [2].

The international concern raised by WHO was found to be escalated among health care workers (HCWs) because they are exposed to increased workload, physical exhaustion, inadequate personal protective equipment (PPE), nosocomial transmission and the need to make ethically difficult decisions on the rationing of care which may have untoward effects on their physical, social and mental well-being. Their resilience can be further compromised by the stigma associated with the disease [3] [4] [5], loss of social support, risk of infection of friends and relatives as well as drastic and often unsettling changes in their working conditions [6]. Therefore, HCWs are the high risk group crucial to the 
COVID-19 outbreak response and as such required to follow established occupational safety and health procedures to avoid exposing others to risk [7].

Since the outbreak of a disease does not occur in a vacuum, definitely, it will originate from a local government area (LGA), a geographical area manned by the LGA rapid response team (LGA RRT) [8]. This rapid response team is led by the LGA disease surveillance and notification officer (DSNO) under the supervision of the Medical Officer of Health with a mandate of outbreak prevention, detection and response [8]. The workforce in the LGA RRT team is basically the primary health care (PHC) workers who play a critical role in reducing the magnitude of community transmission of COVID-19 as presently being witnessed in Nigeria [9]. These roles vary from dispelling rumors about the disease and its management, carrying out house-to-house visits and sensitizing people about the importance of preventive measures such as proper hand washing techniques, use of face masks and how to maintain physical distancing. These identified roles are accomplishable due to the integration of PHC workers in the communities in which they render services, hence, they are seen as a veritable tool in COVID-19 response activities [10].

Subsequently, as the pandemic progresses, and the need for increased testing and mitigation of health care workers' shortages increases, a number of concerns are raised by HCWs in the execution of their duties in relation to COVD-19 response [10]. In the PHC settings, these concerns vary from mental health problems including depression, anxiety, fear, insomnia, poor remuneration, poor social support, lack of basic amenities such as potable water supply and inadequate supply of PPEs. Recent data have also shown that COVID-19 transmission can go undetected in asymptomatic individuals, therefore, exposed HCWs could potentially become asymptomatic carriers and infect patients and/or colleagues [11]. In the light of the above, failure to address these concerns will result to ineffective surveillance activities such as case detection and notification; consequently, the already established community transmission will continue unabated.

Although the size and the consequences of the present outbreak are unknown, many countries are deploying a traditional and vigilant approach of disease surveillance. These are based on case identification (syndromic surveillance), tracing and testing of contacts and high-risk individuals (risk-based surveillance) with daily reporting of infected, recovered and cases of deaths, at area and country levels. This allows treatment and isolation of ill people and quarantine of individuals [12]. These important response activities will suffer a major setback if the needs of the PHC workers who are supposed to drive the vehicle of surveillance are left unmet. Hence, prevention of outbreak through forecasting of cases and informed decision-making as regards to the direction of medical resources or the best timing for community control measures will as well be difficult to achieve [12].

The current onset of community infection and transmission in Nigeria is a wake-up call to redirect our attention to the plight of HCWs, especially the PHC 
workers who form the bulk of the stakeholders in the containment and control of the community transmission of COVID-19. Hence, it is important to increase research into the concerns of the PHC workers, who are the first responders in our health care facilities as this is fundamental towards combating the huge threat to global public health and the health care system constituted by the COVID-19 pandemic. Therefore, this study was carried out to assess the concerns of HCWs working in the PHC facilities in Oyo State, South-Western Nigeria.

\section{Materials and Methods}

\subsection{Study Location}

The study was conducted among primary health care workers in Local Government Health Authorities (LGHAs) of Oyo State. Oyo state is situated in the South-Western part of the country. The State has 33 local government areas (LGAs) with varying incidence of COVID-19 (Figure 1). The state has a projected 2019 population of 8,635,793 using a growth rate of $3.4 \%$ and 2006 population figure as the baseline [13]. Oyo State is predominantly populated by the Yoruba ethnic group with a sparse presence of other ethnic nationalities. The inhabitants are majorly engaged in farming, trading and some of them are artisans and civil servants. Rural-urban migration is a pronounced phenomenon in the state and this was found to result from the predilection for living in high-density urban centres which can rapidly aid the transmission of any disease outbreak. There are 351 political wards in the State and these wards housed 733 primary health care facilities, primary health centers and health posts. In these health facilities, there are 19 Medical Officers of Health (MOH), 224 nurses/midwives, 200 community health officers (CHOs), 589 senior community extension workers (CHEWs), 131 junior community extension workers (JCHEWs), 43 medical laboratory scientists (MLSs), 46 science laboratory scientists (SLTs), 13 pharmacy technicians (PTs), 104 medical record officers (MROs), 890 health assistants (HAs), 122 health attendants (HAtts) and 141 other staff [14].

\subsection{Study Design and Population}

This was an online questionnaire-based, cross-sectional survey carried out among PHC workers in the local government health authorities (LGHAs) of Oyo State between March and April, 2020. The study population included all the PHC workers working in the 33 LGHAs in Oyo State at the time of study. All consenting PHC workers who had been in the service for at least one year were recruited for the study. Medically unfit personnel, administrative staff and casual workers engaged by LGHAs were exempted from the study.

\subsection{Sample Size and Sampling Technique}

The minimum sample size was calculated using the sample size formula for estimating single proportion. Since there was no previous prevalence study of 


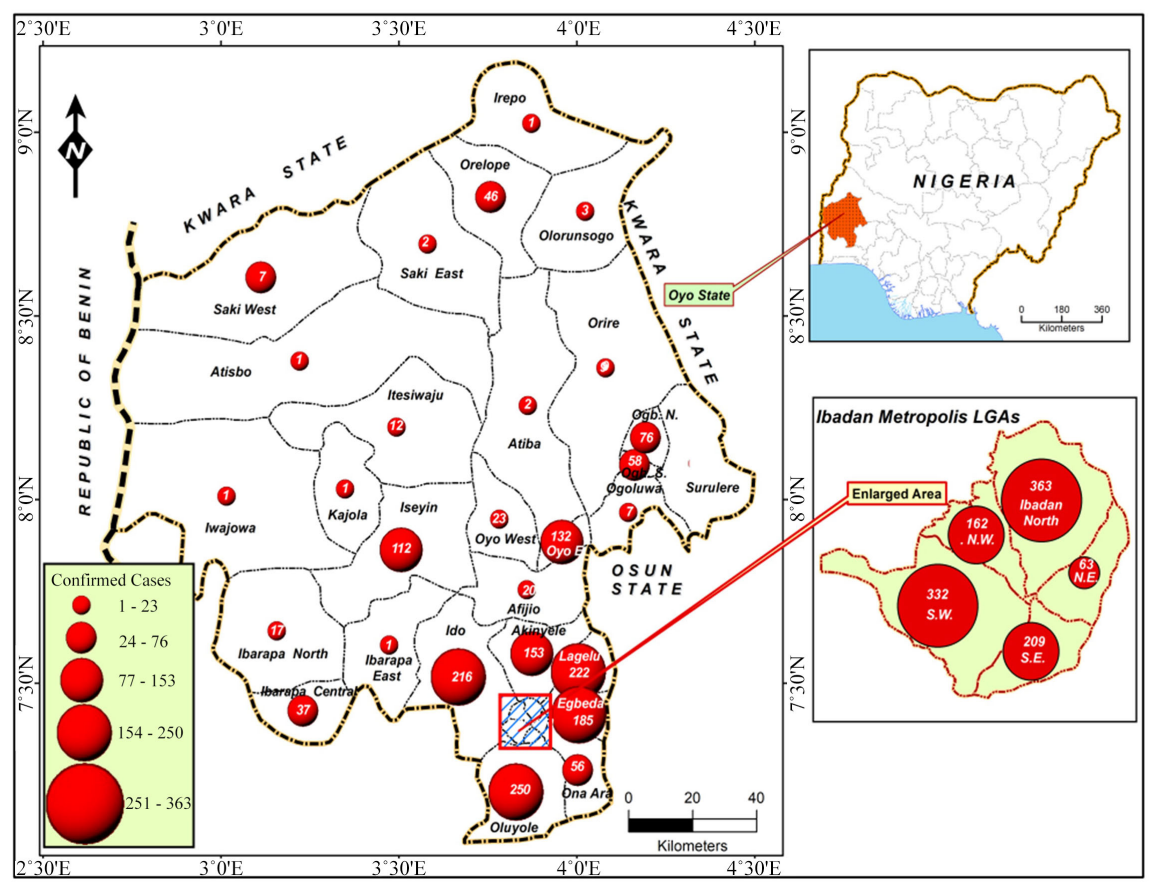

Figure 1. Map of Oyo State showing the LGAs with the number of COVID-19 cases as at 21/07/2020. (Source: Oyo State Administrative Base Map and authors' analysis in ArcMap 10.4.1 version, University of Ibadan ESRI license).

COVID-19 among health workers, a prevalence of $50.0 \%$ was used and the margin of error was set at $5 \%$. A non-response rate of $10 \%$ was envisaged among our respondents and adjustment for this was made to arrive at a minimum sample size of 422. A two-stage sampling technique was used. Stage one: Five LGHAs were selected from the lists of the LGHAs in each of the three senatorial districts by ballot making 15 LGAs in all. Stage two: Three WhatsApp platforms were randomly selected from the list of all WhatsApp platforms of the different cadres in each of the 15 selected LGHAs. The number of PHC workers interviewed was proportionately allocated to the LGHAs.

\subsection{Research Instrument and Data Collection Methods}

Consequent upon the restriction of movement and lockdown order issued out by the Government of Nigeria (GoN), we decided to design an online data collection tool. This collection method was executed using Google Forms (docs.google.com/forms). A total of $460 \mathrm{PHC}$ workers who were members in the several WhatsApp groups were approached to participate in the study. An online data collection tool was designed using Google Forms (via docs.google.com/forms). The Google Form linked to the questionnaire was sent to the participants via the identified WhatsApp groups. A semi-structured questionnaire was developed from previous studies [15] [16] to collect data on socio-demographic characteristics, knowledge about COVID-19 and concern of health workers which include; self-satisfaction related concern, social status related concern, work-related concern and government-related concern. The prepared questionnaire was linked to 
Google Form and sent to the participants via the already identified WhatsApp groups. The administrators of each of the identified WhatsApp groups were contacted on phones before the final dissemination of the questionnaire to the respondents.

\subsection{Validation and Pretest of the Instrument}

The validity and reliability of the questionnaire were done before the final collection of data. Three Nigerian experts in the field of epidemiology and medical statistics in a Nigerian university evaluated the extent to which the variables in the questionnaires were relevant to the objectives of the study. Thereafter, questionnaire was pretested among PHC workers in LGHAs different from the ones used for the main study. The pretest helped to assess the relevance of the questions in producing responses from the participants. Ambiguous questions were either removed or rephrased in line with study objectives. Cronbach's alpha internal consistency reliability of 0.84 was achieved for the analyzed variables.

\subsection{Measurement of Main Outcome Variables}

Knowledge of PHC workers on COVID-19 was assessed using 13 questions adapted from the previous studies [15] [16]. Respondents were scored according to their responses and each correct response was scored one point while each wrong response was scored zero. The total obtainable score was 13. Composite scores were calculated and respondents having $\geq 78 \%$ of the total obtainable score categorized as good knowledge. This scoring system agrees with a study on knowledge of COVID-19 among Chinese residents [17].

The concern of PHC workers about COVID-19 was assessed using an adapted question from a previous study [15] and experts opinion. The Likert scale with five items ranging from strongly disagreed (1) to strongly agreed (5) was used. Responses were scored 1, 2, 3, 4 and 5 in that order to obtain the level of concern score. The sums of the scores for individual respondent were calculated and the mean of all the scores was determined. The mean level of concern's score was 72.4, while the minimum and maximum score were 33.0 and 110.0 respectively. The respondents who scored up to or above the mean were categorized as those with high level of concern about COVID-19.

\subsection{Data Analysis}

At the expiration of the time set for the responses, all the filled questionnaires were extracted from Google Forms and transferred to a Microsoft Excel 2016 for data cleaning and coding. The cleaned data were exported to Statistical Package for Social Sciences (SPSS) version 25 (SPSS Inc, Chicago, IL, IBM Version) for entry and analysis. Univariate analyses were done using frequency distribution tables and charts. In the bivariate analysis, association between level of concern about COVID-19 and socio-demographic variables was determined using Chi Square. For every cell with an expected value less than 5, Fisher's Exact Test was 
used to determine the statistical significance. In the multivariate analysis, binary logistic regression analysis was carried out to determine the demographic predictors of concern of PHC workers about COVID-19. Variables imputed into the logistic model were selected based on their level of significance during bi-variate analysis ( $\mathrm{p}$ value at bivariate was set at $<0.08$ to include more variables). Adjusted odds ratio and $95 \%$ confidence interval were obtained to identify determinants of PHC workers' concern about COVID-19 at $\mathrm{p}$ value of $<0.05$.

\section{Results}

Socio-demographic characteristics of PHC workers in Oyo State, Nigeria-2020

The mean age of the respondents was $45.0 \pm 9.0$ years. The majority $(78.2 \%)$ of the respondents were $\geq 40$ years. The proportion of female respondents was 78.2\%. Married respondents were $92.3 \%$ while $73.2 \%$ were Christians. Almost all (99.7\%) the respondents belonged to Yoruba ethnic group. All the respondents had tertiary education. CHEW/CHO (52.1\%) appeared to be the most prevalent staff cadre followed by nurse/midwife (26.4\%). In the staff category, the proportion of the senior staff was $78.5 \%$. The majority of the respondents had spent 10 years and above while about two-third resided in the rural area (Table 1).

Knowledge of COVID-19 among PHC workers in Oyo State, Nigeria 2020

The proportion of the respondents who had good knowledge of COVID-19 was $52.5 \%$ while $47.5 \%$ of the respondents had poor knowledge of COVID-19 (Figure 2).

Domains of concern about COVID-19 pandemic among PHC workers in Oyo State, Nigeria-2020

The overall proportion of the respondents with high level of concern was $50.7 \%$. In the domains of concern about COVID-19, the government-related concern was the highest (66.9\%) followed by self-satisfaction related concern (53.2\%) and work-related concern (51.4\%) (Figure 3). In the self-satisfaction domain, 59.2\% agreed that they had fast heartbeat whenever they see returnees from other countries, in the social status domain, $91.2 \%$ believed they should limit their social activities due to COVID-19, 63.3\% of the respondents were not confident of current infection prevention and control measures put in place in their workplaces while $96.4 \%$ of the respondents felt that government should isolate COVID-19 cases in a special hospital (Table 2).

Association between socio-demographic characteristics and overall level of concern among PHC workers in Oyo State, Nigeria-2020

The proportion of respondents with high level of concern was greater among PHC workers with $\geq 40$ years (84.7\%) of age compared with those with $<40$ years ( $p$ $=0.071)$. Female respondents $(84.7 \%)$ had higher level of concern compared with their male counterparts. $(\mathrm{p}=0.007)$. The proportion of respondents with high level of concern was more among respondents with monthly income of $\geq 200,000$ ( $\$ 529$ USD) compared with other categories of monthly income $(p=0.072)$ (Table 3$)$. 
Table 1. Socio-demographic characteristics of primary health care workers in Oyo State 2020 .

\begin{tabular}{|c|c|c|}
\hline Socio-demographic variables & Frequency & Percentage (\%) \\
\hline \multicolumn{3}{|l|}{ Age (in years) } \\
\hline$<40$ & 36 & 12.7 \\
\hline$\geq 40$ & 248 & 87.3 \\
\hline \multicolumn{3}{|l|}{ Sex } \\
\hline Male & 62 & 21.8 \\
\hline Female & 222 & 78.2 \\
\hline \multicolumn{3}{|l|}{ Marital status } \\
\hline Single & 10 & 3.5 \\
\hline Married & 262 & 92.3 \\
\hline Separated & 3 & 1.1 \\
\hline Divorced & 3 & 1.1 \\
\hline Widowed/Widower & 6 & 3.1 \\
\hline \multicolumn{3}{|l|}{ Religion } \\
\hline Christianity & 208 & 73.2 \\
\hline Islam & 76 & 26.8 \\
\hline \multicolumn{3}{|l|}{ Tribe } \\
\hline Yoruba & 283 & 99.7 \\
\hline Igbo & 1 & 0.3 \\
\hline \multicolumn{3}{|l|}{ Highest Education } \\
\hline Primary & 0 & 0.0 \\
\hline Secondary & 0 & 0.0 \\
\hline Tertiary & 284 & 100.0 \\
\hline \multicolumn{3}{|l|}{ Staff cadre } \\
\hline Medical Practitioner & 14 & 4.9 \\
\hline Nurse/Midwife & 75 & 26.4 \\
\hline CHEW/CHO & 148 & 52.1 \\
\hline MLS/MLT/SLT & 21 & 7.4 \\
\hline Medical Record & 22 & 7.7 \\
\hline Health Assistant/Attendant & 4 & 1.4 \\
\hline \multicolumn{3}{|l|}{ Staff category } \\
\hline Junior & 49 & 17.3 \\
\hline Middle & 12 & 4.2 \\
\hline Senior & 223 & 78.5 \\
\hline \multicolumn{3}{|l|}{ Number of years in service } \\
\hline$<10$ years & 24 & 8.5 \\
\hline$\geq 10$ years & 260 & 91.5 \\
\hline \multicolumn{3}{|l|}{ Location of Health Facility } \\
\hline Rural & 196 & 69.0 \\
\hline Urban & 88 & 31.0 \\
\hline
\end{tabular}


Table 2. Domains of concern about COVID-19 outbreak among primary health care workers in Oyo State 2020.

\begin{tabular}{|c|c|c|c|c|c|}
\hline Self-satisfaction domains & SD (\%) & $\mathrm{D}(\%)$ & $\mathrm{N}(\%)$ & $\mathrm{A}(\%)$ & SA (\%) \\
\hline $\begin{array}{l}\text { I feel unsafe working in the } \\
\text { PHC environment }\end{array}$ & $102(35.9)$ & $31(10.9)$ & $32(11.3)$ & $27(9.5)$ & $92(32.4)$ \\
\hline $\begin{array}{l}\text { I feel anxious when I see someone } \\
\text { with fever and cough }\end{array}$ & $59(20.8)$ & $35(12.3)$ & $35(12.3)$ & $37(13.0)$ & $118(41.5)$ \\
\hline $\begin{array}{l}\text { My heart beats faster when I see } \\
\text { returnees from other countries }\end{array}$ & $50(17.6)$ & $32(11.3)$ & $34(12.0)$ & $36(12.7)$ & $132(46.5)$ \\
\hline $\begin{array}{l}\text { I feel at risk to contract } \\
\text { COVID-19 in PHC setting }\end{array}$ & $56(19.7)$ & $30(10.6)$ & $32(11.3)$ & $45(15.8)$ & $121(42.6)$ \\
\hline $\begin{array}{l}\text { I feel hopeless I might eventually get } \\
\text { COVID-19 at work }\end{array}$ & $117(41.2)$ & $42(14.8)$ & $43(15.1)$ & $27(9.5)$ & $55(19.5)$ \\
\hline $\begin{array}{l}\text { If I get COVID-19, I don't feel confident } \\
\text { my employer will care for me }\end{array}$ & $101(35.6)$ & $39(13.7)$ & $28(9.9)$ & $33(11.6)$ & $83(29.2)$ \\
\hline \multicolumn{6}{|l|}{ Social status-related domain } \\
\hline $\begin{array}{l}\text { I feel that I should limit my } \\
\text { social activities due to COVID-19 }\end{array}$ & $16(5.6)$ & $4(1.4)$ & $5(1.8)$ & $25(8.8)$ & $234(82.4)$ \\
\hline $\begin{array}{l}\text { I feel that my family will avoid me since I am likely to work } \\
\text { in a facility where suspected cases of COVID-19 might present }\end{array}$ & $96(33.8)$ & $36(12.7)$ & $48(16.9)$ & $34(12.0)$ & $70(24.6)$ \\
\hline $\begin{array}{l}\text { I feel I should avoid leaving } \\
\text { my home due to COVID-19 }\end{array}$ & $135(47.5)$ & $45(15.8)$ & $24(8.5)$ & $20(7.0)$ & $60(21.1)$ \\
\hline $\begin{array}{l}\text { I feel my family will not } \\
\text { look after me if was infected }\end{array}$ & $186(65.5)$ & $35(12.3)$ & $16(5.6)$ & $12(4.2)$ & $35(12.3)$ \\
\hline $\begin{array}{l}\text { I don't feel confident telling } \\
\text { family and friends if I was infected }\end{array}$ & $174(61.3)$ & $38(13.4)$ & $19(6.7)$ & $18(6.3)$ & $35(12.3)$ \\
\hline \multicolumn{6}{|l|}{ Work-related domain } \\
\hline $\begin{array}{l}\text { I feel that my workplace didn't } \\
\text { put control measures in place }\end{array}$ & $61(21.5)$ & $26(9.2)$ & $26(9.2)$ & $38(13.4)$ & $133(46.8)$ \\
\hline $\begin{array}{l}\text { In case I had COVID-19, I feel ashamed } \\
\text { of telling my colleagues at work }\end{array}$ & $176(62.0)$ & $52(18.3)$ & $20(7.0)$ & $11(3.9)$ & $25(8.8)$ \\
\hline $\begin{array}{l}\text { I feel absence from work will reduce } \\
\text { the chance of getting COVID-19 }\end{array}$ & $145(51.1)$ & $33(11.6)$ & $27(9.5)$ & $17(6.0)$ & $62(21.8)$ \\
\hline $\begin{array}{l}\text { I am not confident with the current infection } \\
\text { control measures in place in my workplace }\end{array}$ & $51(18.0)$ & $30(10.6)$ & $23(8.1)$ & 39 (13.7) & $141(49.6)$ \\
\hline $\begin{array}{l}\text { I don't feel proper awareness has been } \\
\text { created within the PHC environment on COVID-19 }\end{array}$ & $102(35.9)$ & $32(11.3)$ & $27(9.5)$ & 33 (11.6) & $90(31.7)$ \\
\hline \multicolumn{6}{|l|}{ Government-related domain } \\
\hline $\begin{array}{l}\text { I feel the government should } \\
\text { restrict travel from/to areas of disease }\end{array}$ & $9(3.2)$ & $5(1.8)$ & $2(0.7)$ & $20(7.0)$ & $248(87.3)$ \\
\hline $\begin{array}{l}\text { I feel the government should isolate } \\
\text { COVID-19 cases in a special hospital }\end{array}$ & $5(1.8)$ & $3(1.1)$ & $2(0.7)$ & $16(5.6)$ & $258(90.8)$ \\
\hline $\begin{array}{l}\text { I feel the government should avoid } \\
\text { inviting expatriates from infected countries }\end{array}$ & $27(9.5)$ & $12(4.2)$ & $15(5.3)$ & $29(10.2)$ & $201(70.8)$ \\
\hline $\begin{array}{l}\text { I don't feel the COVID-19 awareness } \\
\text { and sensitization to the public is enough }\end{array}$ & 73 (25.7) & $33(11.6)$ & $21(7.4)$ & $42(14.8)$ & $115(40.5)$ \\
\hline $\begin{array}{l}\text { I feel there should be a total } \\
\text { lockdown of the affected states }\end{array}$ & $34(12.0)$ & $21(7.4)$ & $23(8.1)$ & $33(11.6)$ & $173(60.9)$ \\
\hline
\end{tabular}

$\mathrm{SD}=$ Strongly Disagreed; D = Disagreed; N= Neutral; A = Agreed; SA = Strongly Agreed. 
Table 3. Association between socio-demographic characteristics and level of concern among PHC workers in Oyo State 2020.

\begin{tabular}{|c|c|c|c|}
\hline \multirow{2}{*}{ Variables } & \multicolumn{2}{|c|}{ Overall level of concern (\%) } & \multirow{2}{*}{$P$ value } \\
\hline & High & Low & \\
\hline \multicolumn{4}{|l|}{ Age (in years) } \\
\hline$<40$ & $22(15.3)$ & $14(10.0)$ & 0.071 \\
\hline$\geq 40$ & $122(84.7)$ & $126(90.0)$ & \\
\hline \multicolumn{4}{|l|}{ Sex } \\
\hline Male & $22(15.3)$ & $40(28.6)$ & $\star 0.007$ \\
\hline Female & $122(84.7)$ & $100(71.4)$ & \\
\hline \multicolumn{4}{|l|}{ Marital status } \\
\hline Single/Others & $9(6.2)$ & $13(9.3)$ & 0.417 \\
\hline Married & $135(93.8)$ & $127(90.7)$ & \\
\hline \multicolumn{4}{|l|}{ Religion } \\
\hline Christianity & $105(73.6)$ & $103(73.6)$ & 0.901 \\
\hline Islam & $39(27.1)$ & $37(26.4)$ & \\
\hline \multicolumn{4}{|l|}{ Tribe } \\
\hline Yoruba & $143(99.3)$ & $140(100.0)$ & 0.323 \\
\hline Others ${ }^{* *}$ & $1(0.7)$ & $0(0.0)$ & \\
\hline \multicolumn{4}{|l|}{ Highest Education } \\
\hline Primary & $0(0.0)$ & $0(0.0)$ & - \\
\hline Secondary & $0(0.0)$ & $0(0.0)$ & \\
\hline Tertiary & $144(100.0)$ & $140(100.0)$ & \\
\hline \multicolumn{4}{|l|}{ Staff category } \\
\hline Junior & $19(13.2)$ & $30(21.4)$ & 0.067 \\
\hline Middle & $4(2.8)$ & $8(5.7)$ & \\
\hline Senior & $121(84.0)$ & $102(72.9)$ & \\
\hline \multicolumn{4}{|l|}{ Monthly income } \\
\hline$<100,000$ & $8(5.6)$ & $5(3.6)$ & 0.072 \\
\hline $100,000-199,999$ & $67(46.5)$ & $84(60.0)$ & \\
\hline$\geq 200,000$ & $69(47.9)$ & $51(36.4)$ & \\
\hline \multicolumn{4}{|l|}{ Years in service } \\
\hline$<10$ & $13(9.0)$ & $11(7.9)$ & 0.723 \\
\hline$\geq 10$ & $131(91.0)$ & $129(92.1)$ & \\
\hline \multicolumn{4}{|l|}{ Facility location } \\
\hline Rural & $95(66.0)$ & $101(72.1)$ & 0.261 \\
\hline Urban & $49(34.0)$ & $39(27.9)$ & \\
\hline \multicolumn{4}{|l|}{ Knowledge } \\
\hline Good & $81(56.3)$ & $68(48.6)$ & 0.195 \\
\hline Poor & $63(43.8)$ & $72(51.4)$ & \\
\hline
\end{tabular}

\footnotetext{
* Significant.
} 


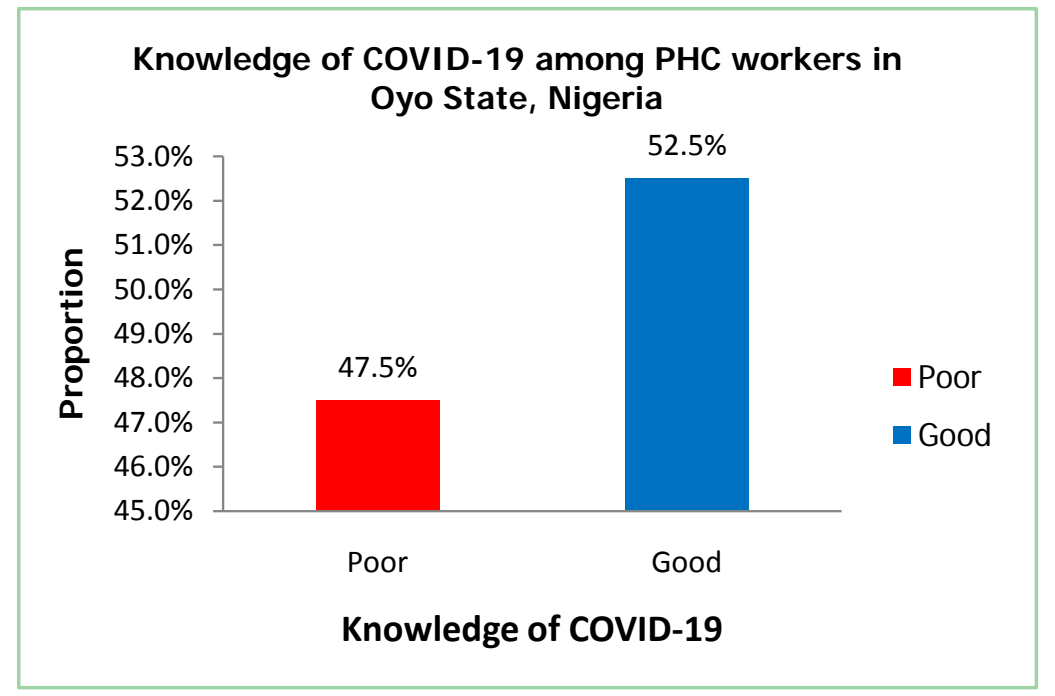

Figure 2. Knowledge of COVID-19 among primary health care workers in Oyo State, Nigeria 2020.

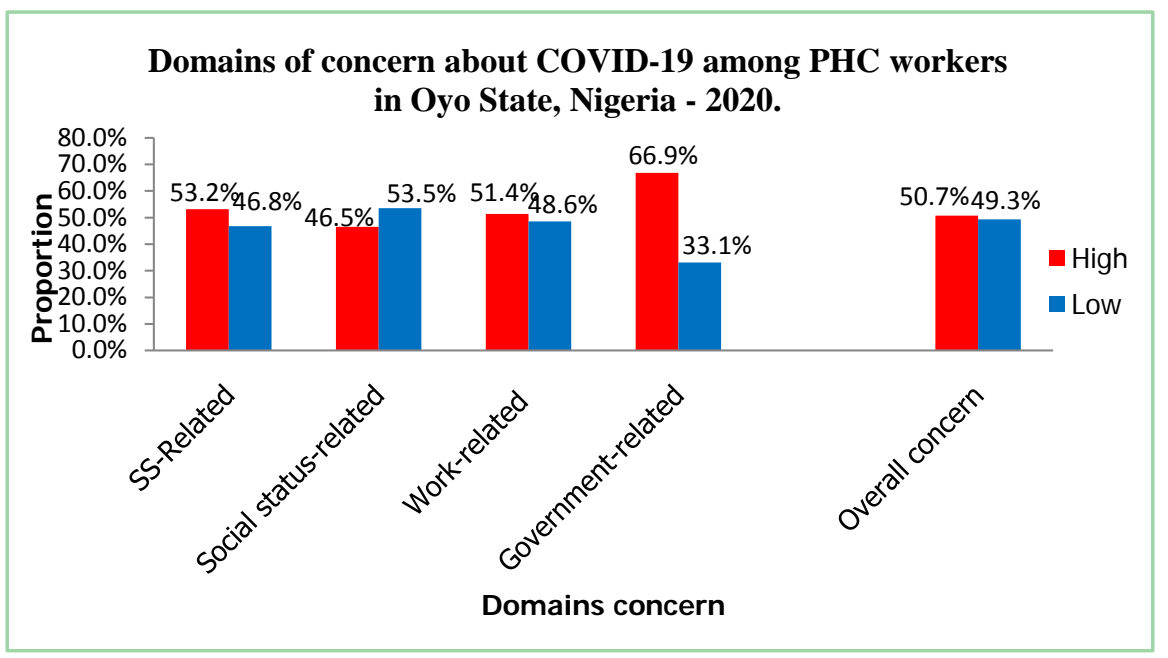

Figure 3. Domains of concern about COVID-19 pandemic among PHC workers in Oyo State, Nigeria 2020. SS = Self-satisfaction.

Association between the staff cadre and concern about COVID-19 among PHC workers in Oyo State, Nigeria-2020

High level of concern about COVID-19 was more prevalent (45.8\%) among $\mathrm{CHEW} / \mathrm{CHO}$ compared with other professionals in the primary health care setting $(\mathrm{p}=0.070)$ (Figure 4$)$.

Association between the staff category and concern about COVID-19 among PHC workers in Oyo State, Nigeria-2020

A higher level of concern about COVID-19 was expressed by respondents in the senior cadre $(84.0 \%)$ compared with other levels of staff cadre $(p=0.067)$ (Figure 5).

Predictors of overall concern about COVID-19 among PHC workers in Oyo State, Nigeria-2020 


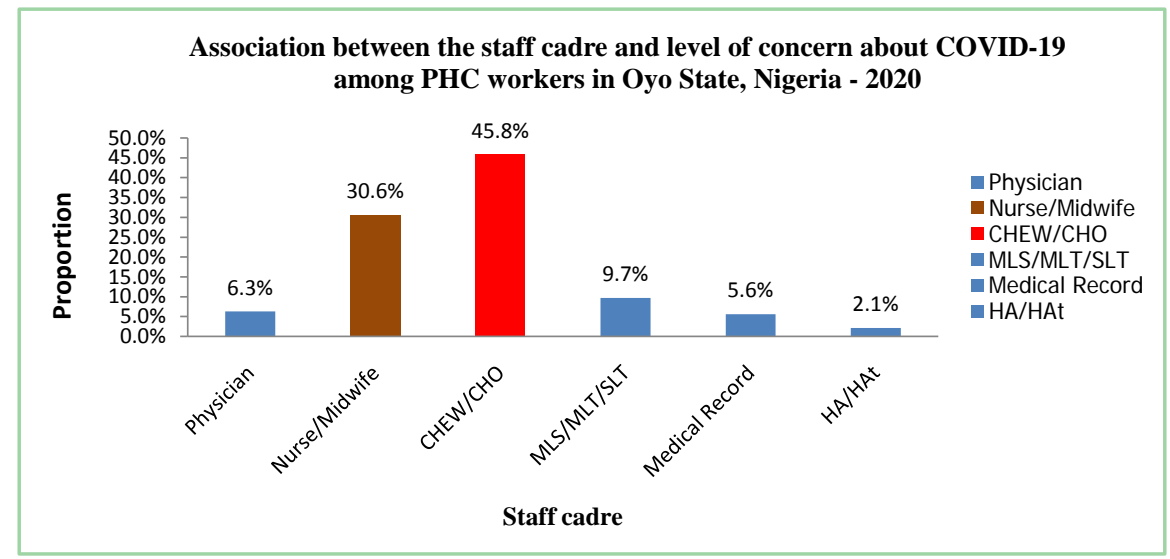

Figure 4. Association between the staff cadre and level of concern about COVID-19 among PHC workers in Oyo State, Nigeria $(\mathrm{p}=0.070)$.

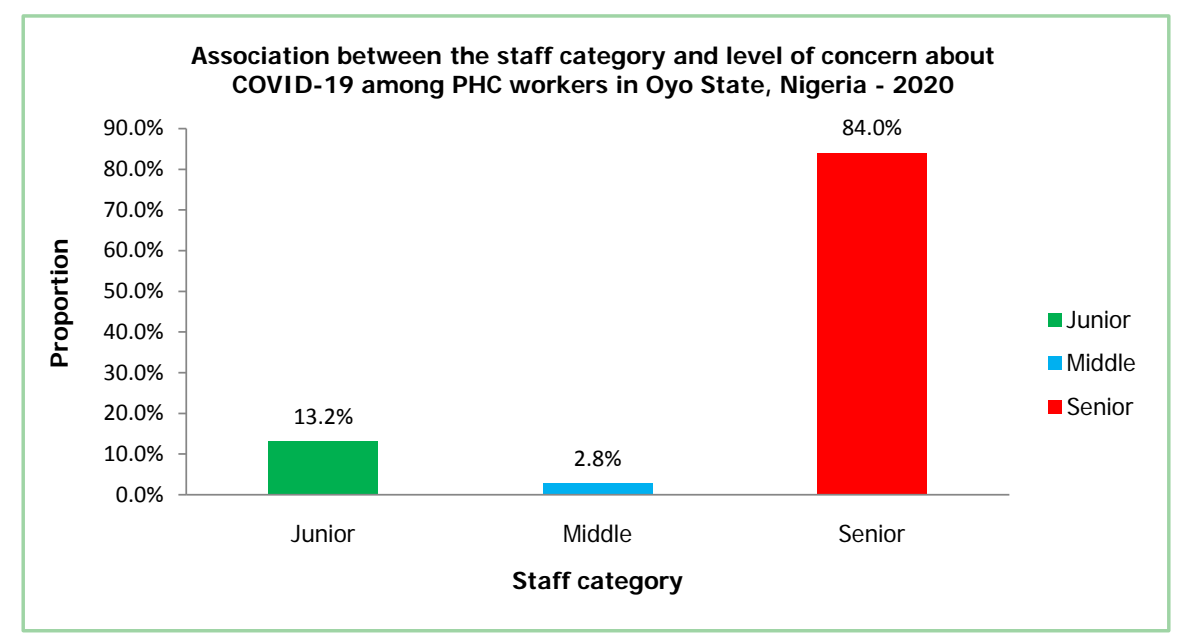

Figure 5. Association between the staff category and level of concern about COVID-19 among PHC workers in Oyo State, Nigeria $(\mathrm{p}=0.067)$.

The male respondents had significant lesser odds (61.0\%) of concern about COVID-19 compared with their female counterparts $(\mathrm{aOR}=0.39,95 \% \mathrm{CI}=$ 0.20 - 0.76). The respondents in the middle cadre were 2.5 times more likely to express concern about COVID-19 compared with junior cadre staff $(\mathrm{aOR}=$ $2.5,95 \% \mathrm{CI}=1.18$ - 5.39). Primary health care workers whose monthly income were $\geq \mathrm{N} 200,000$ had 2.3 times higher likelihood of expressing concern about COVID-19 compared with respondents earning $<$ N100,000 monthly $(\mathrm{aOR}=$ 2.3, $95 \% \mathrm{CI}=1.34-3.92)$. Nurses/midwives were less likely $(79.0 \%)$ to show concern about COVID-19 compared with the respondents in the CHEW/CHO cadre $(\mathrm{aOR}=0.21,95 \% \mathrm{CI}=0.05-0.85)($ Table 4$)$.

\section{Discussion}

The primary health care system is the bedrock of Nigeria's health system and the PHC workers are considered to play crucial roles in health service delivery, particularly during the course of any pandemic [15] [18]. In the current study, the 
Table 4. Predictor of overall concern about COVID-19 among PHC workers in Oyo State 2020 .

\begin{tabular}{|c|c|c|c|c|}
\hline \multirow{2}{*}{ Variables } & \multirow{2}{*}{ Odd Ratio } & \multicolumn{2}{|c|}{ 95\% Confidence Interval } & \multirow{2}{*}{$\mathrm{p}$-Value } \\
\hline & & Lower & Upper & \\
\hline \multicolumn{5}{|l|}{ Age } \\
\hline$<40$ & 1 & & & \\
\hline$\geq 40$ & 0.497 & 0.214 & 1.156 & 0.105 \\
\hline \multicolumn{5}{|l|}{ Sex } \\
\hline Female & 1 & & & \\
\hline Male & 0.390 & 0.201 & 0.757 & ${ }^{*} 0.005$ \\
\hline \multicolumn{5}{|l|}{ Staff category } \\
\hline Junior & 1 & & & \\
\hline Medium & 2.523 & 1.184 & 5.378 & $\star 0.017$ \\
\hline Senior & 2.941 & 0.813 & 10.638 & 0.100 \\
\hline \multicolumn{5}{|l|}{ Monthly income } \\
\hline$<100,000$ & 1 & & & \\
\hline $100,000-199,999$ & 4.357 & 0.677 & 28.028 & 0.121 \\
\hline$\geq 200,000$ & 2.295 & 1.344 & 3.917 & ${ }^{\star} 0.002$ \\
\hline \multicolumn{5}{|l|}{ Staff cadre } \\
\hline $\mathrm{CHEW} / \mathrm{CHO}$ & 1 & & & \\
\hline Health Attendant/Assistant & 0.644 & 0.371 & 1.116 & 0.116 \\
\hline Medical Practitioner & 0.134 & 0.007 & 2.635 & 0.816 \\
\hline Nurse/Midwife & 0.215 & 0.054 & 0.850 & ${ }^{\star} 0.028$ \\
\hline Medical Record & 1.778 & 0.812 & 3.893 & 0.150 \\
\hline MLS/MLT & 1.108 & 0.467 & 2.631 & 0.816 \\
\hline
\end{tabular}

* Significant.

mean age of the respondents was $45.0 \pm 9.0$ years with majority of them being females, this was higher than that reported by a study done in South-South, Nigeria, whose finding showed a mean age of $33.6 \pm 9.3$ years and $57.3 \%$ of the HCWs being females [15]. Geographical variations in the distribution of HCWs across Nigeria, may account for these differences. More than half of the respondents were $\mathrm{CHEWs} / \mathrm{CHO}$ and this could be inferred from the mode of entry of this cadre of PHC workers into their training institution, which is not as rigorous as the nursing profession.

The knowledge of a disease is recognized as an important cognitive key in public health regarding health prevention and promotion. However, our study revealed that slightly above half of the health workers had good knowledge about COVID-19 pandemic. Consistent with this finding was the result of a study by Ogolodom et al., whose study reported that $56.0 \%$ of the HCWs also had good knowledge about the corona virus disease [15]. The newness and unstable epidemiologic pattern of COVID-19 together with limited access to training op- 
portunities among PHC workforce may be responsible for our result. A Nigerian study assessing the preparedness of community health workers to COVID-19, opined that since they are the first responders in the PHCs, it is essential that the staff should be adequately informed and resourced to provide first level care such as screening and referral of patients [18].

Considering the domains of concern about COVID-19 in the current study, about two-thirds of the respondents reported government-related concerns (66.9\%) followed by self-satisfaction related concern (53.2\%) and work-related concern (51.4\%). Our results are at the lower end of outcomes previously reported among HCWs, which also found government policies grossly inconsistent and not feasible to address the fears of majority of the health workers. These fears included lack of social insurance policy (78\%), poor work place safety (62\%), and ineffective hospital infection control policy (89\%) amongst others [15]. This is expected as government policies directly or indirectly affects almost every sector of life, including health sector. Consequently, government must be seen to prioritize the welfare as well as the safety of primary health care workers, by showing political commitment that will address most of the HCWs concerns such as lack of PPEs, inadequate testing capacity, infrastructural decadence, inadequate training and staffing issues.

This study also observed a higher level of concern among over three-quarters of female PHC workers compared with their male counterparts. This is reinforced by a report on COVID-19 which adduced to the fact that majority of the frontline healthcare workers in the COVID-19 response were women [15]. Data from the United States (US) also showed that $76 \%$ of healthcare jobs are held by women and further stratification also revealed that more than 85 percent of nurses, who are generally at the frontline of patient interactions were women [19]. Hence, it raises enormous moral burden about the many risks that women healthcare workers in PHC settings are facing in relation to the COVID-19 pandemic, especially in a low and middle income country like Nigeria.

In the current study, association between the staff cadre and overall level of concern about COVID-19 among primary health care workers revealed a higher level of concern about COVID-19 among nearly half of the CHEWs/CHOs. Going through the training curriculum of these set of PHC workers, they are to spend about $60 \%-70 \%$ of their working hours in the communities attending to public health issues including surveillance activities [20]. As a result, there is an increased likelihood of an infection rate among CHEWs/CHOs compared with other professional cadres whose duties are mostly health facility based. Hence, the reported high level of concern expressed by the CHEWs/CHOs. In the midst of the current economic meltdown, the government of Nigeria should prioritize the available resources for PHC workers, especially community health workers in order to ensure effective surveillance activities in the communities.

This study reports an expression of a higher level of concern about COVID-19 by the majority of the respondents in the senior cadre compared with other staff cadres, although this was not statistically significant. These concerns are well 
founded due to the fact that the PHC staff in the senior cadre are usually older and are more at risk of coming down with complications from COVID-19 compared with other cadres of staff. Older adults are at higher risk of infection and complications related to COVID-19, alongside having underlying medical conditions such as hypertension, diabetes mellitus, cardio-vascular disease, chronic obstructive pulmonary disease and immunosuppression [21] [22] [23]. Therefore, it is imperative that in PHC settings there should be re-assignment of duties to the health care workers based on age and underlying conditions.

Our data indicated the predictors of overall concern about COVID-19 among primary health workers as gender, staff category, monthly income as well as the staff cadre. Consistent with our results, are findings from a related study [24] which also reported same although all healthcare workers are at higher risk and must be protected during COVID-19, it is important to recognize that there are stratified forms of risks and vulnerabilities facing diverse groups of healthcare workers both within and across the health systems [24].

\section{Conclusion}

The study highlights a display of an average knowledge of COVID-19 and identified the domains of government and self-satisfaction related concerns for the majority of the PHC workers. Therefore, as the second wave of COVID-19 is fiercely ravaging, a holistic policy that addresses the welfare and safety of the HCWs, especially among the middle cadre staff, females and high income earner is recommended.

\section{Limitation}

This was a descriptive cross-sectional study design; therefore, inferences on causation could not be established. In addition, this was an online survey; representativeness of all the cadres might not be ascertained as some were excluded due to their poor knowledge in activities involving the use of social media.

\section{Ethical Approval and Consent to Participate}

We obtained the approval for the study from the Ethical Review Committee, Oyo State Ministry of Health. All participants were informed about the study and confidentiality protocols. Online informed consent was obtained from study participants before they could go ahead with the study.

\section{Consent to Publish}

Not applicable.

\section{Availability of Data and Materials}

Upon request, we can offer onsite access to external researchers to the data analyzed at the department of Primary Health Care and Disease Control of Oriire Local Government Health Authority, Ikoyi-Ile, Oyo State, Nigeria. To do so, Dr. 
Olaniyan Akintunde Babatunde should be contacted.

\section{Funding}

No financial support was received for this research.

\section{Authors' Contributions}

$\mathrm{OAB}$ conceptualized the study, $\mathrm{OAB}$ and $\mathrm{MBO}$ contributed to the design, $\mathrm{OAB}$, $\mathrm{MBO}$ and $\mathrm{ARO}$ drafted the initial manuscript, $\mathrm{OAB}, \mathrm{MBO}, \mathrm{ARO}, \mathrm{JMO}$ and $\mathrm{AMB}$ contributed to the analysis, interpretation of the results and made substantial revision to the initial draft. All authors read and approved the final version of the manuscript.

\section{Acknowledgements}

The authors appreciate the PHC workers in all the Local Government Health Authorities for their cooperation and participation. We equally appreciate the management of Oyo State Primary Health Care Board for allowing this survey to be carried out.

\section{Conflicts of Interest}

The authors declare no conflicts of interest regarding the publication of this paper.

\section{References}

[1] World Health Organization (2020) WHO Director-General's Opening Remarks at the Media 25 Briefing on COVID-19-11 March 2020. World Health Organization, Geneva.

https://www.who.int/director-general/speeches/detail/who-director-general-s-openi ng-remarks-at-the-media-briefing-on-covid-19---11-march-2020

[2] World Health Organization (WHO) (2020) https://www.who.int/emergencies/diseases/novel-coronavirus-2019/question-and-a nswers-hub/q-a-detail/q-a-coronaviruses

[3] Nigeria Centre for Disease Control (NCDC) (2020) COVID-19 Case Update. https://twitter.com/NCDCgov/

[4] Nigeria Center for Disease Control (NCDC) (2020) Stigma against COVID-19 Patients Affecting Our Efforts.

https://www.premiumtimesng.com/news/top-news/388339-stigma-against-covid-19 -patients-affecting-our-efforts-ncdc.html

[5] Onyedinefu, G. (2020) Stigmatization of Covid-19 Patients, Significantly Affecting War against Virus.

https://businessday.ng/coronavirus/article/stigmatization-of-covid-19-patients-signi ficant

[6] Pappa, S., Ntella, V., Giannakas, T., Giannakoulis, V.G., Papoutsi, E. and Katsaounou, P. (2020) Prevalence of Depression, Anxiety, and Insomnia among Healthcare Workers during the COVID-19 Pandemic: A Systematic Review and Meta-Analysis. The Lancet. https://doi.org/10.2139/ssrn.3594632 
[7] World Health Organization (2020) Rights, Roles and Responsibilities of Health Workers, Including Key Considerations for Occupational Safety and Health: Interim Guidance-2. World Health Organization, Geneva, 1-2.

[8] Nigeria Centre for Disease Control (NCDC) (2013) Technical Guidelines for Integrated Disease Surveillance and Response in Nigeria. https://www.ncdc.gov.ng/themes/common/docs/protocols/4 1476085948.pdf

[9] Nigeria Center for Disease and Control (NCDC) (2020) Presence of Community Transmission in Lagos, Kano. https://nnn.com.ng/ncdc-says-presence/

[10] National Primary Health care Development Agency (2020) Preparedness and Response to Coronavirus Disease 2019 (COVID-19) at Primary Healthcare and Community Level.

[11] Ng, K., Poon, B., Puar, T., Quar, J., Wong, Y., Tan, T., et al. (2020) COVID-19 and the Risk to Health Care Workers: A Case Report. Annals of Internal Medicine, 172, 766-767. https://doi.org/10.7326/L20-0175

[12] Foddai, A., Lindberg, A., Lubroth, J. and Ellis-Iversen, J. (2020) Surveillance to Improve Evidence for Community Control Decisions during the COVID-19 Pandemic-Opening the Animal Epidemic Toolbox for Public Health. One Health, 9, Article ID: 100130. https://doi.org/10.1016/j.onehlt.2020.100130

[13] Federal Republic of Nigeria (2009) Federal Republic of Nigeria Official Gazette. Legal Notice on Publication of 2006 Census Final Results. Vol. 96, Government of Nigeria, Abuja, B1-B42.

[14] (2019) Ministry of Health. Assessment of Primary Health Care Workforce. Department of Planning, Research \& Statistics, Oyo State, State Secretariat, Ibadan.

[15] Ogolodom, M.P., Mbaba, A.N., Alazigha, N., Erondu, O.F., Egbe, N.O., Golden, I., et al. (2020) Knowledge, Attitudes and Fears of HealthCare Workers towards the Corona Virus Disease (COVID-19) Pandemic in South-South, Nigeria. Journal of Health Science, 19, Article No. 2.

[16] Ronald, O., Gaudencia, C., Godfrey, W., Dianah Rhoda, N. and Felix, B. (2020) Coronavirus Disease-2019: Knowledge, Attitude, and Practices of Health Care Workers at Makerere University Teaching Hospitals, Uganda. Frontiers in Public Health, 8, Article No. 181. https://doi.org/10.3389/fpubh.2020.00181

[17] Zhong, B.L., Luo, W., Li, H.M., et al. (2020) Knowledge, Attitudes, and Practices towards COVID-19 among Chinese Residents during the Rapid Rise Period of the COVID-19 Outbreak: A Quick Online Cross-Sectional Survey. International Journal of Biological Sciences, 16, 1745-1752. https://doi.org/10.7150/ijbs.45221

[18] Ajisegiri, W., Odusanya, O. and Joshi, R. (2020) COVID-19 Outbreak Situation in Nigeria and the Need for Effective Engagement of Community Health Workers for Epidemic Response. Global Biosecurity, 2, 1-10. https://doi.org/10.31646/gbio.69

[19] Yaker, R. (2020) Securing the Safety and Wellbeing of Women Frontline Healthcare Workers in the COVID-19 Response.

[20] Ibama, A.S. and Dennis, P. (2016) Role of Community Health Practitioners in National Development: The Nigeria Situation. International Journal of Clinical Medicine, 7, 511-518. https://doi.org/10.4236/ijcm.2016.77056

[21] Ehrlich, H., McKenney, M. and Elkbuli, A. (2020) Protecting our Healthcare Workers during the COVID-19 Pandemic. The American Journal of Emergency Medicine, 38, 1527-1528. https://doi.org/10.1016/j.ajem.2020.04.024

[22] Mhango, M., Dzobo, M., Chitungo, I. and Dzinamarira, T. (2020) COVID-19 Risk Factors among Health Workers: A Rapid Review. Safety and Health at Work, 11, 262-265. https://doi.org/10.1016/j.shaw.2020.06.001 
[23] Ferdous, M.Z., Islam, M.S., Sikder, M.T., Mosaddek, A.S.M., Zegarra-Valdivia, J.A. and Gozal, D. (2020) Knowledge, Attitude, and Practice Regarding COVID-19 Outbreak in Bangladeshi People: An Online-Based Cross-Sectional Study. PLoS ONE, 15, e0239254. https://doi.org/10.1371/journal.pone.0239254

[24] Smith, C. (2020) The Structural Vulnerability of Healthcare Workers during COVID-19: Observations on the Social Context of Risk and the Equitable Distribution of Resources. Social Science \& Medicine, 258, Article ID: 113119.

https://doi.org/10.1016/j.socscimed.2020.113119

\section{List of Abbreviations}

COVID-19 Coronavirus Disease 2019

SARS-COV-2 Severe Acute respiratory syndrome-coronavirus-2

$\mathrm{PHC}$

HCWs

Primary Health Care

LGAs

Health Care Workers

LGHAs

Local Government Areas

RRT

Local Government Health Authorities

EVD

Rapid Response Team

MERS

Ebola Virus Disease

PHEIC

Middle East Respiratory Syndrome

WHO

Public Health Emergency of International Concern

World Health Organization 